\title{
MODELLING OF LOCALLY GROWN PLANT PROTEIN COSTS FOR PIG FEEDING
}

\author{
Alberts Auzins, Agnese Krievina, Ieva Leimane \\ Institute of Agricultural Resources and Economics, Latvia \\ alberts.auzins@arei.lv, agnese.krievina@arei.lv, ieva.leimane@arei.lv
}

\begin{abstract}
The paper deals with modelling of cultivation and processing costs of locally-grown plant protein in Latvia. Plant protein is a significant component both in animal and human nutrition. Presently, the EU and Latvia's economy, especially animal farming, largely depend on the import of plant protein products. Local production of protein crops has been attracting increased interest recently mainly due to various environmental and climate benefits, as well as advantages of short supply chains. While political initiatives to promote the growing of protein crops locally exist in the EU, the cultivation and processing costs are crucial factors that affect the competitiveness of locally grown plant protein for both animal and human consumption. The article seeks to evaluate the costefficiency of local protein sources for the use as feed ingredients in pig farming. As the content of protein varies among different crops, four protein crops are considered and compared in the study - soybeans, beans, peas and blue lupine. The authors have developed a model that allows to evaluate the cultivation and processing costs of protein crops not only per tonne of crop but also per tonne of crude protein and amino acids, including ideal amino acid balance. The results of this study indicate that local peas and blue lupine have the highest cost-efficiency for pig feeding. Locally grown soya is more expensive; therefore, it can be regarded as the premium source of protein for pig feeding. By changing amino acid profile required in various animal feeds, the model allows assessing the cost-efficiency of local protein crops not only in pig farming, but also in other livestock sectors.
\end{abstract}

Keywords: cost-efficiency modelling, plant protein, pig farming.

\section{Introduction}

Plant protein is a significant component both in animal and human nutrition. Protein is necessary for the major structural components of animal tissues (like muscles) that in animal feeding is largely dependent on the protein provided by plants (feeding animal protein to food producing animals is generally prohibited in the EU). Being important, protein is usually the most expensive component in animal diets, especially when evaluated for the amino acids it provides.

Presently, the EU and Latvia's economy, especially animal farming, largely depend on the import of plant protein products. Apart from import dependency reduction considerations and frequent price fluctuations of soybean meal, local production of protein crops has been attracting increased interest recently mainly due to various environmental and climate benefits, their contribution to the improvement of local soils, and the possibility to position such products as non-GMO and locally grown, coupled with other various advantages of short supply chains $[1 ; 2]$.

Currently imported GMO soybean meal is the most-widespread protein source used in pig feeding in the EU and Latvia. To develop more sustainable and GMO-free offer by pig farming that can meet the changing customer preferences and the green course of agricultural policy [3], the inclusion of locally grown protein plants in feed recipes needs to be considered. To fulfil the potential of alternative protein sources, it is believed that constraints including inadequate supply and anti-nutritional factors should be addressed [4]. At the same time, there are studies that have shown no adverse effects of replacing soybean meals with alternative protein sources on growth performance of growing-finishing pigs [5]. While political initiatives to promote the growing of protein crops locally exist in the EU [1], the cultivation and processing costs are crucial factors that affect the competitiveness of locally grown plant protein for both animal and human consumption.

The paper seeks to evaluate the cost-efficiency of local protein sources for the use as feed ingredients in pig farming. As the content of protein varies among different crops, four protein crops are considered and compared in the study - soybeans, beans (faba beans), peas (field peas) and blue lupine. The paper first focuses on the comparison of the characteristics of these protein plants as feed ingredients for pigs, followed by the evaluation of the cultivation and processing costs of protein crops not only per tonne of crop but also per tonne of crude protein and amino acids, including per ideal amino acid balance.

\section{Materials and methods}

The main data sources for the study are information and empirical data obtained within the agricultural European Innovation Partnership (EIP-AGRI) project "New Technologies and 
Economically Viable Solutions for the Production of Local Feed for Pig Production: Cultivation of Nongenetically Modified Soybeans and New Barley Varieties in Latvia”, including unpublished information provided by the project's partners, as well as market data on agricultural commodities. The model of locally grown protein costs comprises the following blocks.

1. Modelling of the full cultivation costs of protein crops: soybeans, beans, peas and blue lupine.

2. Modelling of processing costs, if processing is necessary (soybeans and blue lupine need to be heattreaded prior to feeding to pigs).

3. Calculation of the full costs (cultivation and processing), and modelling of the costs for actual products used in pig feeding.

4. The calculation of protein costs per different indicators.

The costs of growing are estimated according to the method used by the authors in their previous research [2]. The costs of growing include the costs of seeds (also inoculants), fertilisers, pesticides, agro-technical works, transportation (from field to farm), cleaning and drying. To estimate the processing costs of soybeans, extrusion-expelling is considered, as it is the only processing technology commercially used for soybeans in Latvia [2]. At present, hardly any processing of blue lupines for pig feeding exists in Latvia, while to estimate the processing costs of blue lupine, extrusion is used as it is both technically and economically feasible (it is possible to adapt the existing technology of extrusionexpelling). Unpublished data on commercial soybean, bean, pea and blue lupine growing [6], combined with the unit costs of agricultural inputs and agro-technical operations provided by the Agricultural gross margin calculations for 2019 (Latvian Rural Advisory and Training Centre) [7] serve as input data for the modelling of the growing and processing costs.

In the case of soybeans and blue lupine, already processed product is used in pig feeding. As the extrusion of lupine gives only one product, the full costs of growing and processing is calculated per tonne of extruded lupine. The extrusion and expelling of soybeans yield two products - soybean cakes or mechanically expelled soybean meal (contains protein) and soybean oil. Therefore, the full growing and processing costs of soybeans are allocated between soybean cakes and soybean oil based on the economic nutrient units. The following formulae are used for the allocation of the full cultivation and processing cost of soybeans:

$$
\begin{aligned}
& c_{F_{-} s c}=c_{F_{-} s b} \cdot \frac{E N U_{s c}}{y_{s c} \cdot E N U_{s c}+y_{s o} \cdot E N U_{s o}}, \\
& c_{F_{-} s o}=c_{F_{-} s b} \cdot \frac{E N U_{s o}}{y_{s c} \cdot E N U_{s c}+y_{s o} \cdot E N U_{s o}},
\end{aligned}
$$

where $\quad c_{F_{-} s c}-$ full costs per tonne of soybean cakes, EUR per tonne of dry matter (DM);

$c_{F_{-} s b}-$ full costs per tonne of soybeans, EUR per tonne of DM;

$c_{F_{-} s o}-$ full costs per tonne of soybean oil, EUR per tonne of DM;

$y_{s c-}$ obtained soybean cakes, tonnes of DM per tonne of soybean DM;

$y_{s o-}$ obtained soybean oil, tonnes of DM per tonne of soybean DM;

$E N U_{s c-}$ economic nutrient units, tonnes per tonne of soybean cake DM;

$E N U_{s o-}$ economic nutrient units, tonnes per tonne of soybean oil DM.

The economic nutrient units $(E N U)$ is the concept developed by the authors. It is a complex indicator that measures the content of basic nutrients - protein, sugars plus starch, fat (lipids). This indicator allows allocating not only the full costs of soybeans between soybean cakes and soybean oil, but also the full costs of the products among the nutrients, thus allowing to calculate and model protein costs as well. The $E N U$ for a product (soybean cakes, soybean oil, beans, peas, extruded lupine) is calculated by applying the following formula:

$$
E N U_{p(D M)}=\alpha \cdot \lambda_{p r_{-} p}+\lambda_{s+s_{-} p}+\beta \cdot \lambda_{f_{-} p},
$$

where $E N U_{p(D M)}-E N U$ for a product, tonnes per tonne of a product DM;

$\alpha$ - ratio of the market price of protein to the market price of sugars and starch;

$\lambda_{p r_{-} p}-$ protein content in a product, $\%$ of DM;

$\lambda_{s+s_{-} p}-$ content of sugars and starch in a product, $\%$ of $\mathrm{DM}$; 
$\beta$ - ratio of the market price of crude fat to the market price of sugars and starch; $\lambda_{f_{-} p}-$ fat (crude fat) content in a product, $\%$ of DM.

The market price of protein, fat, sugars and starch is determined by applying the approach developed within the authors' previous study [2]. Nevertheless, some modifications have been made to this approach. First, maize is used instead of feed wheat as a reference product for sugars and starch due to its higher content of sugars and starch. Second, GMO soybean meal instead of non-GMO soybean meal is used as a reference product for protein when calculating the market price of sugars and starch (at present, the calculated market price of protein is higher if GMO soybean meal is used as a reference product for protein, which the authors regard as a market shortcoming). Third, more than one indicator is used to measure protein, in addition to crude protein, the following indicators are applied - the sum of selected amino acids (SSAA), the sum of selected amino acids expressed on a standardized ileal digestible (SID) basis for pig feeding $\left(S S A A_{S I D}\right)$, the sum of selected digestible amino acids in terms of balanced protein $\left(S S A A_{S I D \_}\right.$balanced $)$. The latter is an indicator developed by the authors, which reflects the part of $S S A A_{S I D}$ that is balanced (according to the concept of ideal protein for pigs). The following algorithm is used to calculate the content of $S S A A_{S I D \_b a l a n c e d}$ in a product (feed ingredient).

1. The ratios of digestible amino acids to digestible lysine in a product are compared to the concept of ideal protein in order to determine the smallest value $(k)$ :

$$
k=\min \left\{\frac{\text { Cont_a }\left\{a_{-} S I D_{i}\right.}{C o n t_{-} l y s_{S I D}} / r_{i}\right\},
$$

where Cont_aa_SID - content of digestible amino acid i in a product;

Cont_lysSID - content of digestible lysine in a product;

$r_{i}$ - ideal ratio of the amino acid i to lysine (ideal protein concept).

2. If $k<1$ (4), the content of SSAASID_balanced is calculated as follows:

$$
\text { Cont_SSAA } \text { SID_balanced }=k \cdot \text { Cont_lys }_{S I D} \cdot \frac{100+\sum_{j=1}^{n} r_{j}}{100},
$$

where Cont_SSAA $A_{S I D}$ balanced - content of digestible $S S A A_{S I D \_b a l a n c e d}$ in a product;

Cont_lysSID - content of digestible lysine in a product;

$r_{j}$-ideal ratio of the amino acid $\mathrm{j}$ (other amino acids except lysine that is 100) to lysine (ideal protein concept);

$n$-number of the other amino acids;

3. If $k \geq 1$ (4), the content of $S S A A_{S I D \_b a l a n c e d}$ is calculated as follows:

$$
\text { Cont_SSAA } \text { SID_balanced }_{2}=\text { Cont_lys }_{S I D} \cdot \frac{100+\sum_{j=1}^{n} r_{j}}{100},
$$

For the study, the authors have selected the following significant amino acids in pig feeding - lysine (lys), methionine (met), cystine (cys), threonine (thr), isoleucine (ile), leucine (leu), valine (val), histidine (his), phenylalanine (phe). At the same time, the model allows changing the amino acids included, as well as operate both at individual amino acids and the combinations of amino acids (e.g., met + cys) level. Different views exist about the concept of ideal protein and ideal ratios of amino acids to lysine. Nevertheless, the authors have used the following ratios for the calculations: lys -100 , met + cys -59, thr -64 , ile + leu + val + his + phe -425 .

The long-term market prices of the reference products (rapeseed oil, soybean meal, maize) collected and provided by Indexmundi.com [8], Donau Soja [9] and European Commission (Price monitoring data) [10] are used to calculate the market price of fat, sugars and starch, protein and to estimate the coefficients $\alpha$ and $\beta$. The values of $a$ coefficient $\alpha$ vary by the protein indicator (crude protein, SSAA, $S S A A_{S I D}, S S A A_{S I D_{-} \text {balanced }}$, and the lowest $\alpha$ is for crude protein, the highest $\alpha$ - for $S S A A_{S I D_{-} \text {balanced. }}$ 
According to the authors' estimates, $\alpha$ is 8.0 for crude protein, 21.2 for $S S A A, 24.6$ for $S S A A_{S I D}$ and 29.1 for of $S S A A_{S I D \_b a l a n c e d}$, while the value of the coefficient $\beta-6.2$.

Protein costs are calculated from the full costs per tonne of a product and $E N U_{p(D M)}$ by applying the following formula:

$$
C_{-} \text {prot }_{p}=\frac{C_{F_{-} p}}{\text { Cont }_{-} D M_{p}} \cdot \frac{\alpha}{E N U_{p(D M)}},
$$

where $\quad$ C_prot protein $_{p}$ costs of a product, EUR per tonne of protein (i.e., crude protein, SSAA, $S S A A_{S I D}$ or $\left.S S A A_{S I D \_b a l a n c e d}\right)$;

$C_{F_{-}}$- full costs of growing and processing, EUR per tonne of a product;

Cont_DM - content of DM in a product;

$\alpha$-coefficient $\alpha$ according to the applied protein indicator (i.e., crude protein, SSAA,

$S S A A_{S I D}$ or $\left.S S A A_{S I D \_b a l a n c e d}\right)$.

Formula (7) is used to model protein costs for of all four protein indicators - per crude protein, per $S S A A$, per $S S A A_{S I D}$ and per $S S A A_{S I D_{-} \text {balanced. }}$

\section{Results and discussion}

\section{Protein crops as pig feed ingredients}

Soybeans belong to the legumes family but are classified as oilseeds [11; 12]. Most soybeans produced in the world are crushed to produce oil and soybean meal (beans contain about $20 \%$ oil and $40 \%$ protein) - the major source of protein and indispensable amino acids in non-ruminant feeding [1214]. About $75 \%$ of the world's soybean meal is fed to pigs or poultry as a premier source of amino acids [13]. Diets for poultry and pigs predominantly consist of cereals, with soybean meal as the main source of protein (granivores' diets contain higher levels of soybean meal than ruminants') [4]. Soybean meal and other soy products provide pigs with high quality protein that is rich in lysine, threonine and tryptophan - the most limiting amino acids in cereals. Though not ideal (complements cereals), soybean protein balance of indispensable limiting amino acids is superior to other plant proteins, as well as amino acids in soya protein can be better digested by pigs than most other common protein sources $[11 ; 13]$.

Conventional soybean meal is produced by extracting the oil with a solvent (usually hexane), while mechanical extraction of the oil from soybeans results in the production of the by-product soybean cakes $[15 ; 16]$. Mechanical extraction is less efficient than chemical, so the oil contents in soybean cakes is greater than in soybean meal. Soybeans like other legumes contain anti-nutritional factors that reduce nutrient utilization (most notably trypsin inhibitors), therefore, to be included in pigs' diets all soybean products must be prior heat-treated thus inactivating trypsin inhibitors [11; 15].

Soybeans are the most grown legumes in the world [17]. The production of soybeans is still comparatively small in the EU, though, increasing [2]. In 2019, about 2.7 million tonnes of soybeans were produced in the EU, as opposed to the total EU feed consumption of soybean meal standing at around 30 million tonnes [18]. The main challenges for the cultivation of soybeans in the EU currently are low yields and long growing season [12]. In Latvia, the production of soybeans has also started to attract wider attention and questions about its growing costs and efficiency have arisen. Presently, the cultivation of soybeans in Latvia cannot be considered for bulk production, but soybean cakes produced from on-farm grown soya could be a competitive feed ingredient in local chains. The quality of locally sourced soybean products in Latvia is found to be equal to the imported soya [19].

Farmers grow grain legumes (pulses) for their seeds to be consumed by humans and animals, with peas being the most cultivated and established grain legume in Europe, mainly grown to meet protein requirements of animals $[12 ; 20 ; 21]$. The total EU production of peas was 2.2 million tonnes in 2019, while feed use totalled 1.9 million tonnes [18]. Currently, peas are the second most cultivated pulses in Latvia [22]. The use of peas in animal feeding in the world has developed only over the past 50 years that has been facilitated also by the fact that peas can be cultivated in areas where other protein sources cannot be grown (cool-season alternative to soybeans) [15; 20]. However, as all legumes, peas suffer from a wide range of diseases and pests [23]. In recent years, peas are receiving increasing interest in the EU to be used as protein source for food and feed [12]. Peas contain about $22 \%$ protein that has a relatively high lysine content, but low concentration of methionine, cysteine, and tryptophan compared 
to soybean protein, while the digestibility of most amino acids by pigs is comparable to the soybean meal [15]. Although peas contain less crude protein and lysine than soybean meal, it is more than grains [24]. They have 5 to $20 \%$ less trypsin inhibitors than soybeans that makes possible to feed dry peas directly to livestock without extrusion heating process [21]. Apart from young pigs, it is considered that peas can be included in growing-finishing pig diets as an alternative protein source without affecting the growth performance [25].

Beans are the second most cultivated grain legumes in Europe [12] and the pulses most sown in Latvia [22]. The EU production of beans was 1.7 million tonnes in 2019, with the total EU feed consumption standing at 1.2 million tonnes [18]. The chemical composition of beans is close to peas with about $22-28 \%$ of protein, also digestibility of its amino acids and the concentrations of trypsin inhibitors in beans is close to the values reported for peas [15]. Peas and beans can be considered as a viable alternative protein source to soybean meal in nutritionally balanced grower and finisher pig diets [26].

High protein content (35\%) makes lupines an interesting crop, considered as a possible alternative to soybean meal in diets for monogastric animals [12;[27], though, compared to soybean meal in pig diets, lupines have imbalanced amino acid profile and lower amino acid digestibility [27]. The EU production of lupines was 0.3 million tonnes in 2019, with 0.4 million tonnes used as feed [18]. Lupines contain hardly any trypsin inhibitors but have toxic alkaloids, which are bitter tasting and may reduce food intake [12]. Among other technologies, extrusion is used to improve the nutritional value of lupines [28]. If lupine-based diets are formulated on equal amounts of digestible amino acids, performance of pigs can be comparable or superior to the pigs fed soybean meal-based diet [29].

\section{Modelled plant protein costs for pig feeding}

The results of the model indicate that local peas and blue lupine have the highest cost-efficiency for pig feeding (see Table 1 and Table 2).

Full costs of cultivation and processing of local protein crops in Latvia

\begin{tabular}{|c|c|c|c|c|}
\hline \multirow{2}{*}{ Indicator } & \multicolumn{4}{|c|}{ Crop } \\
\hline & Soybeans & Beans & Peas & Blue lupine \\
\hline Field costs, EUR per tonne of crop* & 316 & 136 & 110 & 88 \\
\hline After-field costs, EUR per tonne of crop** & 8 & 10 & 10 & 8 \\
\hline Full growing costs, EUR per tonne of crop & 324 & 146 & 120 & 96 \\
\hline Processing costs, EUR per tonne of crop & 45 & - & - & 35 \\
\hline Full costs, EUR per tonne of crop & 369 & 146 & 120 & 131 \\
\hline Product & Soybean cakes & Beans & Peas & Extruded lupine \\
\hline \multicolumn{5}{|c|}{ Full costs*** according to the protein indicator used, EUR per tonne of product } \\
\hline crude protein & 355 & 146 & 120 & 131 \\
\hline SSAA & 351 & 146 & 120 & 131 \\
\hline$S S A A_{S I D}$ & 352 & 146 & 120 & 131 \\
\hline SSAA $A_{S I D \_b a l a n c e d}$ & 351 & 146 & 120 & 131 \\
\hline
\end{tabular}

* costs of seeds, fertilisers, pesticides, agro-technical works

** costs of transportation (from field to farm), cleaning and drying

*** choice of indicator matters only for soybeans, as the processing yields two products - soybean cakes and soybean oil Source: the authors' calculations

Peas have the lowest full costs (cultivation and processing) per product among the compared local protein crops (120 EUR per tonne), rather closely followed by blue lupine with about $9 \%$ higher costs. Peas and blue lupine also have the lowest protein costs for all four protein indicators. However, blue lupine excels in terms of balanced digestible amino acids (SSAASID_balanced). One tonne of digestible amino acids of blue lupin fed to pigs is evaluated to be by $17 \%$ cheaper than that of peas, the cost advantage over beans is by $42 \%$ and for soybean cakes reaches even $48 \%$. While peas are not only the cheapest, but also a common protein crop suitable for growing in local conditions, it seems that the potential of blue lupin as a protein source in pigs' diet could be currently underrated. Considering lower cost advantages, the potential of blue lupin for wider use in pig feeding is promising. As feed costs 
account for the largest share of the costs in pig farming, by replacing more expensive sources of protein in pigs' diets with cheaper alternatives even partly, it is possible to increase the profitability of pig farmers. Furthermore, the need to reduce protein losses in feed within the climate change context calls for increased focus on the costs of balanced digestible amino acids instead of the costs of crude protein.

Beans that are currently the most popular local protein crop in Latvia show a medium cost potential. The full cultivation and processing costs per tonne of beans are by about $22 \%$ higher than for peas, the difference is less for crude protein costs (beans are by $11 \%$ more expensive), but it expands for balanced digestible amino acids $\left(S S A A_{S I D \_b a l a n c e d}\right)$ (beans are by $44 \%$ more expensive), the latter being much more pronounced in comparison with blue lupin.

Protein content and calculated protein costs of locally grown protein crops in Latvia

\begin{tabular}{|c|c|c|c|c|}
\hline \multirow{2}{*}{ Indicator } & \multicolumn{4}{|c|}{ Crop } \\
\hline & Soybeans & Beans & Peas & Blue lupine \\
\hline Product & Soybean cakes & Beans & Peas & Extruded lupine \\
\hline \multicolumn{5}{|l|}{ Biochemical parameters: } \\
\hline Content of crude protein (in DM), \% & 39.5 & 28.7 & 24.5 & 30.6 \\
\hline Content of SSAA (in DM), \% & 13.7 & 9.7 & 8.9 & 10.5 \\
\hline Content of $S S A A_{S I D}$ (in DM), \% & 12.0 & 7.7 & 7.1 & 9.2 \\
\hline Content of $S S A A_{S I D \_ \text {balanced }}$ (in DM), \% & 10.0 & 3.8 & 4.5 & 7.7 \\
\hline Content of sugars and starch (in DM), \% & 4.7 & 51.8 & 61.0 & 9.8 \\
\hline Content of crude fat (in DM), \% & 8.7 & 1.7 & 1.7 & 5.6 \\
\hline Content of DM, \% & 93.3 & 86.0 & 86.0 & 86.0 \\
\hline \multicolumn{5}{|l|}{ Protein costs: } \\
\hline Costs of crude protein, EUR per tonne & 813 & 466 & 418 & 422 \\
\hline Costs of SSAA, EUR per tonne & 2291 & 1345 & 1136 & 1209 \\
\hline Costs of $S S A A_{S I D}$, EUR per tonne & 2625 & 1670 & 1392 & 1390 \\
\hline Costs of $S S A A_{S I D \_b a l a n c e d}$, EUR per tonne & 3145 & 2868 & 1993 & 1649 \\
\hline
\end{tabular}

Source: the authors' calculations

Growing of soybeans locally is the most complicated and expensive among the studied local protein crops. The cultivation and procession costs of soybeans are at least twice as high than for other local protein sources, also protein costs of soybean cakes are considerably higher. At the same time, soybeans can be regarded as the premium source of protein for pig feeding due to its amino acid profile and very high content of $S S A A_{S I D \_b a l a n c e d}$. At the same time, the protein costs of locally grown soybean cakes are lower than the protein costs of imported non-GMO soybean meal.

According to the authors' calculations, if the 3-year average price of imported non-GMO soybean meal is used in the model, the protein costs are the following: per tonne of crude protein - $1008 \mathrm{EUR}$, per tonne of SSAA - 2658 EUR, per tonne of SSAA $A_{S I D}-3085$ EUR, and per $S S A A_{S I D \_b a l a n c e d}-3644$ EUR. Thus, all four analysed locally grown protein crops outperform imported non-GMO soybean meal. Furthermore, inclusion of locally grown plant protein feed ingredients in pigs' diets provides a nonprice competitive advantage for the promotion of pork on the market.

It should be mentioned that the application possibilities of the model developed by the authors are wider than demonstrated by the results of the study, e.g., modelling of the impact of coupled support for protein crops on net protein costs, modelling of protein costs for different tillage systems, modelling of protein costs for other livestock (cattle, poultry) feeding. The model also allows modelling protein costs for different crops and in different countries (regions).

\section{Conclusions}

1. Among four feed ingredients with different protein content considered in the study for the modelling, the costs of locally grown peas, blue lupine and beans stand out as compared to soybean cakes, the cultivation and procession costs of which are at least twice as high. 
2. Blue lupin is potentially an underrated low-cost local protein source, especially when the costs of balanced digestible amino acids (SSA $\left.A_{S I D_{-} \text {balanced }}\right)$ are considered. Peas are a common protein crop suitable for growing in local conditions, with comparatively low protein costs. Cultivation of beans is also common, and overall, they have medium cost potential. Cultivation of local soybeans is more complicated and protein costs of soybean cakes are higher. However, locally grown soybeans can be regarded as the premium source of protein for pig feeding.

3. Although soybean cakes from locally grown soybeans have higher protein costs than other local feed ingredients, they outperform imported non-GMO soybean meals by lower protein costs. Furthermore, the inclusion of locally grown plant protein feed ingredients in pigs' diets provides a non-price competitive advantage for the promotion of pork on the market.

4. The results of the modelling of locally grown plant protein costs indicate that local blue lupine, peas and beans can contribute to the performance of pig farming, as by replacing more expensive protein feed ingredients in pigs' diets with cheaper alternatives even partially, it is possible to increase the profitability of pig farmers.

5. The model developed by the authors provides wider application possibilities to model protein costs than demonstrated by the study, e.g., modelling of the impact of coupled support for protein crops on net protein costs, modelling of protein costs for different tillage systems, modelling of protein costs for feeding of other livestock.

\section{Acknowledgements}

The paper was prepared in the framework of the project "New Technologies and Economically Viable Solutions for the Production of Local Feed for Pig Production: Cultivation of Non-genetically Modified Soybeans and New Barley Varieties in Latvia". The authors would like to thank Dr.oec. Andris Miglavs for valuable suggestions on the development of the concept of economic nutrient unit.

\section{References}

[1] Report from the Commission to the Council and the European Parliament on the development of plant proteins in the European Union. [online] [12.02.2021]. Available at: https://eurlex.europa.eu/legal-content/EN/TXT/?uri = CELEX\%3A52018DC0757

[2] Auzins A., Leimane I., Krievina A. Prospects of Latvian-grown Soya as a Local Protein Source for Pig Feeding. Proceedings of International Multidisciplinary Scientific GeoConference SGEM, August 18-24, 2020, Sofia, Bulgaria, pp. 947-954.

[3] Communication from the Commission to the European Parliament, the European Council, the European Economic and Social Committee and the Committee of the Regions The European Green Deal. [online] [9.02.2021]. Available at: https://eur-lex.europa.eu/legalcontent/EN/TXT/?uri = CELEX:52019DC0640

[4] Wilkinson J. M., Young R. H. Strategies to reduce reliance on soya bean meal and palm kernel meal in livestock nutrition. Journal of Applied Animal Nutrition, 8(2), 2020, pp. 75-82.

[5] Grabež V., Egelandsdal B., Kjos N. P., Håkenåsen I. M., Mydland L. T., Vik J. O., ... Øverland M. Replacing soybean meal with rapeseed meal and faba beans in a growing-finishing pig diet: Effect on growth performance, meat quality and metabolite changes. Meat science, 166, 2020, 108134.

[6] Unpublished farm data on soybean, bean, pea and blue lupine costs and quality.

[7] Lauksaimniecības bruto seguma aprēkini par 2019.gadu (Agricultural gross margin calculations for 2019), Latvian Rural Advisory and Training Centre. (In Latvian) [online] [19.02.2021]. Available at: http://new.llkc.lv/lv/nozares/augkopiba-ekonomika-lopkopiba/provizoriskie-lauksaimniecibasbruto-seguma-aprekini-par-2019

[8] Commodity prices, Index Mundi. [online] [19.02.2021]. Available at: https://www.indexmundi.com/commodities/

[9] Soybean meal prices, Donau Soja. [online] [19.02.2021]. Available at: https://www.donausoja.org/en/dses-soya-bean-meal-prices/

[10]EU representative market prices for cereals, DG Agri. [online] [19.02.2021]. Available at: https://ec.europa.eu/info/food-farming-fisheries/farming/facts-and-

figures/markets/overviews/market-observatories/crops/cereals-statistics_en

[11] Dei H. K. Soybean as a feed ingredient for livestock and poultry. IntechOpen, 2011, pp. 215-226. 
[12] Cultivation, processing and nutritional aspects for pigs and poultry of European protein sources as alternatives for imported soybean products, Wageningen UR. [online] [17.02.2021]. Available at: https://core.ac.uk/download/pdf/77084797.pdf

[13] Stein H. H., Roth J. A., Sotak K. M. Rojas O. J. Nutritional value of soy products fed to pigs. Swine Focus, 4, 2013.

[14] Ibáñez M. A., de Blas C., Cámara L., Mateos G. G. Chemical composition, protein quality and nutritive value of commercial soybean meals produced from beans from different countries: A metaanalytical study. Animal Feed Science and Technology, 267, 2020, 114531.

[15] Stein H. H., Lagos L. V. Casas G. A. Nutritional value of feed ingredients of plant origin fed to pigs. Animal Feed Science and Technology, 218, 2016, pp. 33-69.

[16] Moura E. D. S., Silva L., Bumbieris Junior V. H., Ribeiro E. D. A., Peixoto E. L. T. Mizubuti I. Y. Use of soybean cake replacing soybean meal in diets of lambs. Semina: Ciências Agrárias (Londrina), 36(3), 2015, pp. 1643-1654.

[17] Faostat Crops. [online] [16.02.2021]. Available at: http://www.fao.org/faostat/en/\#data/QC

[18] EU + UK Feed Protein Balance Sheet, DG Agri. [online] [19.02.2021]. Available at: https://ec.europa.eu/info/sites/info/files/food-farming-fisheries/farming/documents/eu-uk-feedprotein-balance-sheet_2019-2020_en.pdf

[19] Jansons I., Degola L., Sterna V., Zute S. Influence of local extruded soybean cake and imported soybean meal on fattening pig productivity and pork quality. Agronomy Research, 18(S2), 2020, pp. 1307-1315.

[20] Jezierny D., Mosenthin R., Bauer E. The use of grain legumes as a protein source in pig nutrition: A review. Animal Feed Science and Technology, 157(3-4), 2010, pp. 111-128.

[21] The Global Economy of Pulses, FAO. [online] [22.02.2021]. Available at: http://www.fao.org/3/i7108en/i7108en.pdf

[22] Sown area, total crop production, yield of agricultural crops, CSB of Latvia. [online] [22.02.2021]. Available at: http://data1.csb.gov.lv/pxweb/en/lauks/lauks_03Augk_ikgad/LAG020.px/

[23] Watson C. A., Reckling M., Preissel S., Bachinger J., Bergkvist G., Kuhlman T., ... Stoddard F. L. Grain legume production and use in European agricultural systems. Advances in Agronomy, 144, 2017, pp. 235-303.

[24]Hugman J., Wang L. F., Beltranena E., Htoo J. K. Zijlstra R. T. Growth performance of weaned pigs fed raw, cold-pelleted, steam-pelleted, or extruded field pea. Animal Feed Science and Technology, 264, 2020, 114485.

[25] Hugman J., Wang L.F., Beltranena E., Htoo J.K. Zijlstra R.T. Nutrient digestibility of heatprocessed field pea in weaned pigs, Animal Feed Science and Technology, 2021.

[26] White G. A., Smith L. A., Houdijk J. G. M., Homer D., Kyriazakis I. Wiseman J. Replacement of soya bean meal with peas and faba beans in growing/finishing pig diets: Effect on performance, carcass composition and nutrient excretion. Animal Feed Science and Technology, 209, 2015, pp. 202-210.

[27] Pieper R., Taciak M., Pieper L., Święch E., Tuśnio A., Barszcz, M., ... Zentek, J. Comparison of the nutritional value of diets containing differentially processed blue sweet lupin seeds or soybean meal for growing pigs. Animal Feed Science and Technology, 221, 2016, pp. 79-86.

[28] Tuśnio A., Barszcz M., Święch E., Skomiał J. Taciak M. Large intestine morphology and microflora activity in piglets fed diets with two levels of raw or micronized blue sweet lupin seeds. Livestock Science, 240, 2020, 104137.

[29] Kim J. C., Pluske J. R. Mullan B. P. Lupins as a protein source in pig diets. Pig News and Information, 28(2), 2007. 